\title{
Neo-extractivist controversies in Bolivia: indigenous perspectives on global norms
}

\author{
Jessika Eichler \\ Research Fellow at the Law \& Anthropology Department of Max Planck Institute, and FU Berlin, Latin American Institute, \\ TrAndeS, Lateinamerika-Institut, Berlin, 10589, Germany \\ E-mail: jessika.eichler@gmail.com
}

\begin{abstract}
Ever since Evo Morales Ayma became Bolivia's first indigenous president in 2006 and the promulgation of a human-rights-enhancing Constitution (2009) thereafter, indigenous peoples' rights were gradually recognised. Yet, with the increasing demand for natural resources, indigenous communities have been adversely affected by the state's neo-extractivist policies. While global indigenous rights norms protect their fundamental rights, legal-implementation processes in the country's lowlands reveal dilemmas in terms of the value of laws in practice as well as its reinterpretation on the ground. Namely, in the communities, different positions and camps have emerged in terms of the role and functions of participatory rights. Despite the potential of the latter in strengthening collective-rights regimes and self-determination, community leaders, advisers and other members report how such processes fracture and weaken decisionmaking mechanisms and human rights claims.
\end{abstract}

Keywords: human rights; indigenous perspectives; participatory rights; decision-making mechanisms; natural resources; Bolivia

\section{Introduction}

In 2009, Bolivia witnessed one of the most far-reaching legal developments in terms of indigenous peoples' rights at world scale: the establishment of the plurinational state of Bolivia in its new Constitution and accompanying policies that would guarantee indigenous peoples' rights as well as political, social, economic, judicial, cultural and linguistic pluralism (Böhrt Irahola, 2010). That way, the state is built on differences instead of a homogenising process. Alongside Ecuador, the Bolivian Constitution constitutionally recognises 'plurinationality' in Latin America representing a new form of constitutionalism called 'transformative constitutionalism' (Wolkmer and Wolkmer, 2015; Clavero, 2010): it refounds the state, reinvents institutions and promises the end of colonialism (Baldi, 2012). It thereby represents the latest form of what Raquel Yrigoyen termed 'three phases of constitutional recognition of legal pluralism' (2011, p. 140).

At the same time, international legal developments strongly influenced the incorporation of indigenous peoples' rights in the Constitution: the UN Declaration on the Rights of Indigenous Peoples (UNDRIPS), for instance, shaped the instrument in terms of collective rights, namely selfdetermination and sovereignty issues on the one hand and the equal recognition of indigenous justice systems on the other (Sieder and Sierra, 2010). In turn, UNDRIPS was turned into a national law (No. $3760)^{1}$ in 2007 following its adoption by the UN General Assembly, which made its implementation at the national level an indispensable undertaking. The second international legal instrument of indigenous peoples' rights ILO $\mathrm{C}_{169^{2}}$ had been ratified by the Bolivian National Congress by means of the

\footnotetext{
${ }^{1}$ The Bolivian National Congress adopted the 'Ley No. 3760' in 2007, making UNDRIPS a legal obligation.

${ }^{2}$ The Convention concerning Indigenous and Tribal Peoples in Independent Countries (C169) was adopted by the International Labour Organisation (ILO) in 1989 and entered into force in 1991.

(c) Cambridge University Press 2018
} 
National Congress Act No. 1257 in 1991. Similarly, a national law on hydrocarbons (No. 3058) ${ }^{3}$ was adopted regulating prior-consultation processes in the sector as prescribed by international law; the Morales government further spelt out prior-consultation obligations as a regulation in the form of Supreme Decree No. 29033. Consulting indigenous peoples was considered a transversal obligation and also taken up in other laws including the internationally known Law on Mother Earth (No. 300), ${ }^{4}$ which establishes a plural economic model, and the 'Vivir Bien'5 principle (Bascopé Sanjinés, 2012). It could be argued that legal developments in Bolivia adopted local traditions and practice in an outstanding fashion being driven by new indigenous actors.

Conversely, economic policies gradually eroded socio-environmental standards and indigenous collective-rights regimes in Morales's current and last terms of office consolidating a neoliberal model that favours the corporate sector. Morales's intention to run for a fourth term was accompanied by an extensive campaign that promoted a constitutional referendum that would allow extending the two-consecutive-terms-of-office rule for Bolivia's presidents (The Guardian, 2016): after the referendum was decided against his plans, alternative ways and strategies of confronting the constitutional limit were considered. The Constitutional Tribunal eventually declared electoral laws on the temporary nature of the president's mandate unconstitutional in the name of political rights (BBC Mundo, 2017). The longevity of the Morales administration has indeed favoured the establishment of long-term extractivist policies in the form of specific laws regulating concessions and other forms of access to natural resources. Conversely, neoliberal market tendencies and capital accumulation come with a local impact (Pred and Watts, 1992) and catalyse exceptionally high levels of resource extraction in indigenous territories (Hinojosa et al., 2015). Bolivia exemplifies an alarming case, as it has become the largest exporter of natural gas in Latin America (Postero, 2017; Kaup, 2010), which particularly affects indigenous communities: at least ten of the national protected areas are reserved for exploration and exploitation of hydrocarbons mainly affecting indigenous peoples' territories (López Camacho, 2015). In fact, 83 per cent of the national gas reserves are located on the Guaraní people's lands in the Bolivian lowlands (Perreault, 2008). This also resulted in a number of consultation proceedings with Guaraní people. After the adoption of respective laws regulating prior-consultation processes, approximately forty processes took place, among which thirty involved Guaraní people (Schilling-Vacaflor, 2014).

The processes were carried out according to Bolivian law regulating prior consultation in accordance with international legal norms, particularly with aforementioned ILO C169 and UNDRIPS. Accordingly, consultation (and participation) processes are to be conducted prior to the approval and even planning stage of extractive, infrastructure or development projects including indigenous peoples in all stages of the project, providing sufficient access to information and free from coercion or any other form of pressure exerted on the free decision taken by the communities. Consultation processes shall further be conducted with the objective of reaching indigenous peoples' free, prior and informed consent (FPIC). In some cases, such objective becomes a right according to international law, namely in the case of forced relocation, military activities or the disposal of hazardous materials (UNDRIPS). However, practice shows that the right to prior consultation has been increasingly reduced to a mere administrative process illustrated by a couple of decrees that are less stringent in terms of the negative impacts caused by hydrocarbon projects. One of them reduced the maximum duration to forty-five days instead of sixty, ${ }^{6}$ a second establishes high maximum levels of permissible

\footnotetext{
${ }^{3}$ The Bolivian National Congress adopted the 'Ley No. 3058 de Hidrocarburos' in 2005.

${ }^{4}$ The Bolivian Legislative Assembly adopted the 'Ley Marco de la Madre Tierra y Desarrollo Integral para Vivir Bien No. 300 ' in 2012.

${ }^{5}$ The principle 'Vivir Bien' (or Sumaj Kamaña, Sumaj Kausay, Yaiko Kavi Päve) was defined by David Choquehuanca (Bolivian Minister of Foreign Affairs) as 'living in harmony with nature and takes up the regional cultures' ancestral principles'. The aforementioned Law 300 provides further insights into its definition in Art. 5(2): 'The Vivir Bien is the civilizing horizon and cultural alternative to capitalism and to modernity which rises in the cosmovisions of indigenous campesino nations and peoples as well as intercultural communities and Afrobolivians and is being conceived in the intercultural context.'

${ }^{6}$ The constitutional president of Bolivia adopted Supreme Decree No. 2298 in 2015.
} 
water discharge and hydrocarbon-related contamination with a high environmental impact, ${ }^{7}$ the third decree allows hydrocarbon projects in natural reserves, ${ }^{8}$ which was met with tremendous opposition from Guaraní assemblies, and a forth decree limited compensation payments for adverse socioenvironmental impacts to 1.5 per cent of the total project investment. ${ }^{9}$ At the same time, civil society actors were explicitly targeted by Bolivian Law No. 351 on granting legal personalities and Supreme Decree No. 1597 in case the former intervened in the extractive sector and jeopardised 'Bolivia's economic development' or impeded the 'process of change' proclaimed by the country's president (Layme, 2015): this included measures such as denying non-governmental organisations (NGOs) legal personality, which they depend on for acquiring external funding or criminalising public protest in the mining sector (Francescone, 2015). Yet, indigenous peoples' voices were among the most excluded ones, often silenced through not consulted or imposed gas projects in the context of such recent developments.

It is these very voices that the author attempts to unveil, drawing on extensive empirical research in indigenous communities and highlighting indigenous peoples' perspectives on global norms. Extensive fieldwork in the communities enabled the author to capture such views. The communities lived in the indigenous communal lands (Tierra Comunitaria de Orígen, TCO) of Alto Parapetí, which are situated in the south-west region of the Santa Cruz Department bordering the Department of Chuquisaca. The author spent one year (April 2014 to April 2015) in the Bolivian lowlands collaborating with the Bolivian NGO Centre for Judicial Studies and Social Research (CEJIS Bolivia) in advising indigenous communities in a prior-consultation process with state and company representatives that took place from May to August 2014. In the aftermath of the process, the author revisited the communities to conduct in-depth interviews and focus groups about the impressions and perceptions on the implementation of the law on prior consultation in the hydrocarbon sector. The interviews were coded for themes and focused on the participation of different groups within the communities as well as internal dynamics between the actors and within the communities that would influence the consultation process. Previously, the author had trained two sociology students who were native speakers in Guaraní in her research methodology so that fieldwork could be conducted in Guaraní and in Spanish in order to reach all community members.

In this paper, the author will build on this empirical experience to explore the significance, meaning and role of international human rights law and indigenous rights in particular through indigenous communities' eyes. This includes indigenous leaders and decision-makers, indigenous advisers to the prior-consultation process and community members who were either directly involved in the consultation or were excluded, but formed part of the communities affected by the gas-exploration project. First, basic theoretical insights into the literature on implementation, localisation or vernacularisation of global norms in local contexts will be given. Second, the prior-consultation regime in Bolivia's hydrocarbon sector and how the former is shaped by international developments are looked at. Third, empirical insights will provide an understanding of how global norms are used in priorconsultation regimes on the ground, how the law is being perceived and what role it plays in enhancing collective claims or, conversely, catalyses social conflicts or dismantles social cohesion within or between communities. Fourth, the empirical findings are related to a current socio-environmental land conflict and its implications for indigenous participation and their use of the law in the Territorio Indígena y Parque Nacional Isiboro Sécure (TIPNIS) case. Finally, the observations made and voices heard will be translated back into the law by making concrete proposals on how existing standards could be revised to accommodate local perspectives and prevent common implementation dilemmas.

\footnotetext{
${ }^{7}$ Supreme Decree No. 2400 was adopted by the Bolivian constitutional president in 2015.

${ }^{8}$ Supreme Decree No. 2366 was adopted by the president in 2015.

${ }^{9}$ The constitutional president adopted Supreme Decree No. 2195 in 2014.
} 


\section{Localising human rights: legal-anthropological approaches for studying indigenous rights}

To understand the impact of human rights law on societies beyond court decisions and jurisprudence more generally requires insights from other disciplines. In the field of legal studies, indigenous peoples' is not considered a complex term (Robyn et al., 2005), yet ethnographic research reveals its complexities and the multiplicities inherent in this legal category. In fact, cultural identities are far from static and 'ethnic lines between the powerful and dispossessed' can hardly be created (Fontana and Grugel, 2016, p. 257), as ethnic identities reflect fluidity and social constructs (Lucero, 2006): cultural practices are rarely coherent; instead, identities are constructed in a dynamic way (Behabib, 2002). In this paper, a legal-anthropological framework was chosen in order to the discuss double-sided ways in which international norms are implemented by state representatives on the one hand and shaped and responded to by indigenous communities. The promises of law in the form of international legal commitments are observed, focusing on connections, commonalities, differences, inconsistencies and contradictions (Pirie, 2013). Especially the plurality among indigenous peoples' realities and views indicates differences and contradictions between and also within communities; by contrast, the nature of collective claims and the pan-indigenous movement promise connections and commonalities. The chosen approach also lends itself to trigger or influence normative change and can assume an enabling function in the sense of translating indigenous demands into legal claims or, as Goodale puts it, 'transform the framework through which the idea of human rights itself is understood' (2007, p. 4).

In yet a different manner, legal-anthropological approaches can be used to reveal marginalisation, as they focus on identifying the over-looked and singling out the unrepresented (Dresch and James, 2000). Thereby, the approach allows examination of how norms are appropriated or vernacularised in particular contexts (Merry, 2006b) and serves to explain the impacts of international law (Merry, 2006a). Nevertheless, norms appropriation includes not only individual leaders or decision-making bodies, but also indigenous peoples' rules, customs and traditions, which hybridise with the existing hegemonic order, often inspired by post-colonial standard setting, but also by international indigenous standards that were framed by the indigenous peoples movement. The term interlegality (de Sousa Santos, 1995) has been used to illustrate such space, which describes the interactions of both legal spheres going beyond mere co-existence. In a similar fashion, indigenisation describes concepts and norms that are contextualised in cultural practices (Merry, 2006c). In this paper, it is critically observed to what extent the law actually assumes such a role, which presupposes indigenous peoples' active participation in its shaping opposed to camouflaging elites and power (Comaroff and Comaroff, 2008).

In the Bolivian context, questions of indigenisation and indigeneity take a particular form as power struggles not only exist between indigenous and non-indigenous populations, but are of an intra-indigenous nature. Evo Morales Ayma's government represents the country's highlands/Andes and with it Quechua and Aymara people, while the country's lowland people including Guaraní communities hardly occupy politically important positions. Such asymmetries materialise in extractive policies in the gas sector, where lowland people are most affected, whereas the country's Andean capital takes considerable economic benefit. In fact, it was noted elsewhere that extraction is based on a system of cultural differences and racialised patterns of oppression (Fabricant and Postero, 2015). That way, inequalities are enhanced between different indigenous groups in a context of territorial claims and fights for natural resources. It could also be argued that indigenous lowland groups are excluded in light of a national indigenous culture (Canessa, 2014).

Even the new Constitution was subjected to criticism based on its Aymara-centric character (Albró, 2010) and the paradox of new exclusions (Toranzo Roca, 2008). This might be attributed to the complexities of integrating thirty-six indigenous groups and subgroups into one single legal language. The 'campesino' character of the very definition of indigenous peoples in the Bolivian context demonstrates difficulties in opening the legal definition for urban populations. However, significant difficulties arise in practice where indigenous peoples as rights holders can make legal claims that might conflict with community members. This is also reflected in laws and policies that are drafted in the 
country's capital depriving indigenous groups from their right to participate in the drafting and legislative process as stipulated in UNDRIPS: remote communities might not have accessed urban spaces of negotiation and law-making due to lacking accessibility, resources and infrastructure-related reasons. Similarly, systemic difficulties including language and education barriers create distance and hence inequalities in the law-making, prior-consultation processes (Eichler, 2016) and constitutional-drafting processes that underlie the entire legal apparatus without reflecting some form of intentional policies of exclusion. At the international level, by contrast, indigenous peoples' active engagement and contributions in the drafting process of UNDRIPS are considered some of its main successes (Willemsen Diaz, 2009). The following chapters shed new light on such paradoxes in the way indigenous peoples shape global norms and how this is being played out in current conflicts exemplified by the TIPNIS issue.

\section{Prior consultation in Bolivia and the influence of international law}

Internationally, Bolivia became known as a role model for indigenous peoples' identity and rights when Evo Morales assumed power in 2006 and the new Constitution was adopted in 2009. Subsequently, UNDRIPS became legally binding once it was incorporated into the national legal order through laws and regulations. The influence of international legal standards also materialised in other laws: both the hydrocarbon law and the accompanying regulation ${ }^{10}$ make explicit references to international standards and accommodate key components of consultation processes, including its legally binding nature, appropriateness, participation, transparency, comprehensiveness and good faith (Art. 115, hydrocarbon law; Art. 4, regulation). In accordance with international law, the prior character of the process was stipulated in relation to various measures (Arts 115(a), (b), hydrocarbon law; Arts 14-15, regulation) as well as the objective of reaching indigenous peoples' agreement or consent (Art. 115, hydrocarbon law; Considerations, regulation). Yet, the latter is seriously undermined by another provision which allows processes that finalise without final agreement to be decided in the 'best national interest' (Art. 116, hydrocarbon law); such contradictions reveal the active contributions of different parties in the drafting process (Muguerza, 2011) and resemble the complexities inherent in UNDRIPS, which reserves exemptions from indigenous rights as determined by law and where states' territorial integrity or political unity is at stake.

On the bright side, law and regulation contain extensive references to maintaining indigenous peoples' own decision-making in accordance with customs and traditions just as proclaimed in UNDRIPS. One of the cornerstones of the declaration is the respect for indigenous peoples' cultural rights, selfdetermined development and self-determination, including the right to practise cultural traditions and customs in the context of their representative institutions and consultation processes (Wiessner, 2011; Anaya, 2009; Regino Montes and Torres Cisneros, 2009): indeed, the recognition and protection of indigenous peoples' customs and traditions run through the entire declaration as a transversal principle. Similarly, the regulation on prior consultation in Bolivia requires consultation processes to be representative in the sense that indigenous peoples' representative decision-making entities, forms of organisation as well as customs and traditions need be respected; in an even further-reaching way, it stipulates rules that guarantee the independence (Art. 4, regulation). Namely, it rules out any interference, intrusion or influence on indigenous organisations' internal affairs (Art. 4, regulation). International obligations as to respecting and recognising indigenous customs and traditions are given due regard here: indigenous organisations and competent authorities are not only to be recognised at all levels (local, regional, departmental, national); the transversal principle of respecting territoriality, customs and traditions is particularly mentioned in that regard (Art. 6, regulation). Such progressive developments in laws and regulations were accompanied by judgments issued by the Bolivian Constitutional Court that supported compliance with international human rights standards and their integration into the Bolivian judicial legal order ${ }^{11}$ and the constitutional block including

\footnotetext{
${ }^{10}$ The constitutional president of Bolivia adopted Supreme Decree No. 29033, which included the Regulation on Consultation and Participation for Hydrocarbon Activities, in 2007.

${ }^{11}$ Bolivian Constitutional Court (Tribunal Constitucional de Bolivia) in Decision No. 1662/2003-R issued in 2003.
} 
the human rights catalogue. ${ }^{12}$ In a more recent judgment, the importance of indigenous organisational structures is reaffirmed while attributing to them the power and competences to apply their own norms where conflicts arise (Lenzerini, 2014). ${ }^{13}$

Despite its promising beginnings, the newly established indigenous rights system was increasingly undermined in the course of Morales's three terms of office. This becomes particularly visible in the way indigenous peoples' rights and prior-consultation regimes are framed in existing laws and policies. In 2014, such rights came under threat when a mining law was adopted criminalising public protest and allowing resource exploration without prior consultation. Indigenous peoples' opposition was specifically strong, since affected populations had been excluded from the drafting and negotiation process of the law and led to the convening of two social summits in the Bolivian highlands and lowlands (Andreucci and Radhuber, 2015). Again, the law declared natural resources as a strategy and in the public interest for Bolivia's development, and thereby denied indigenous peoples' final say in the consultation process ruling out prior consent (Art. 208, mining law). ${ }^{14}$ More controversies were caused as the state ceased to be the main actor in mining activities and provided (foreign) mining companies with considerable protection from the state (Robb et al., 2015). Similar developments in terms of diminishing indigenous rights guarantees are expected in the hydrocarbon sector, where particularly Guaraní people were affected by extractive operations in natural reserves and decision-making mechanisms were ignored in recent years (Guidi, 2015).

\section{The role of law on the ground: enhancing claims or instrumentalising exclusions?}

Interestingly, legal discourses on the ground evolve around the recurrent theme of individual rights and women's rights or gender issues in particular. Female interviewees repeatedly pointed to the importance of women's rights that had helped them to legitimise leading positions and assuming political mandates in the past few years. Structural demographic factors had facilitated such changes: due to extreme dry seasons in the Bolivian Chaco area, male workers had been forced to leave the communities to find work elsewhere. This had produced political vacuums in the communities, which were rapidly filled by young indigenous women. Frequent references to international legal discourses and women's rights in the Bolivian legal order assisted in maintaining such positions, also when their husbands, sons and brothers returned to the communities during harvest season, as these interviews reveal:

'There is no disagreement here (on their newly assumed positions), this is included in all norms ... that women have the same rights, there is nothing like that here (discrimination), we are all equal!' (In-depth interview in Spanish with male, middle-aged community member, 16 October 2014)

'We as women participate now, now we do hold positions while it was only men in the past .... Women are the ones who participate most while most men do not at all, there are no products (in the sense of crops) now, so they are forced to leave and don't participate.' (Focus group in Guaraní and Spanish with female, middle-aged community members, 13 October 2014)

'Especially women assume mandates too nowadays. In the past this option did not exist, but now with the change of laws and workshops, they now say 'gender equality' and they are more prepared as a consequence, now they do whatever type of work in the community.' (In-depth interview with male, elderly community member, 17 October 2014)

\footnotetext{
${ }^{12}$ Bolivian Constitutional Court (Tribunal Constitucional de Bolivia) in Decision No. 1420/2004-R issued in 2004.

${ }^{13}$ Bolivian Constitutional Court (Tribunal Constitucional de Bolivia) in Decision No. 0045/2006-R issued in 2006.

${ }^{14}$ Bolivian Legislative Assembly (Asamblea Legislative Plurinacional del Estado Plurinacional de Bolivia) adopted the Law on Mining and Metallurgy No. 535 in 2014.
} 
Surprisingly, such changes were not reflected in or translated into the prior-consultation process and thereby into the collective-rights sphere. Rather, such development stayed in isolated ways at the community level, as an indigenous community leader recounted:

'It is true that women only participate here in the community, but when it comes to going elsewhere, to Cuevo or Camiri (where official meetings with e.g. state representatives are held), they do not participate ... and this worries me, because despite the existence of laws, women continue to live in the same situation.' (In-depth interview in Guaraní with male, middle-aged indigenous leader, 15 October 2014)

As these words suggest, it is precisely collective decision-making that does not sufficiently consider female leaders in negotiations, or alternatively imposes structural barriers that lead to their exclusion.

Such findings differ from existing studies on indigenous women's rights, which hold that patriarchal structures and power relations are to be blamed for limiting indigenous women's access to resources and political participation (Kuokkanen, 2012). Alternatively, consistent violations of indigenous peoples' collective rights show adverse consequences for indigenous women as individuals or individual groups (McKay and Benjamin, 2010) in this case: women's newly conquered position is undermined under the umbrella of general participation gaps and democratic deficits in the consultation process, as the following paragraphs show. Conversely, women's active local voices could be used to strengthen collective claims and prevent elitism inherent in indigenous organisation that have been administering compensation payments for centuries. In fact, individual and collective rights, it could be advanced, are mutually interactive instead of competitive (Eichler, 2016; Corntassel and Holder, 2002). It could even be argued that collective and individual rights regimes enter into dialogue, allowing both collective solidarity and individual autonomy (Freeman, 1995). Such complementarity also resembles indigenous societies and modus operandi much more than contradictions between both sets of rights: responsible, respectful and reciprocal communal conduct is often observed in that context (Sneider, 2015; Ackerman and Klein, 2000; Souza, 1997). In the present case, the nature of these processes does not find similar expression in encounters with the state and companies having implication not only for women's rights, but also for indigenous peoples' rights to maintain and practise customs and traditions more generally.

In point of fact, other community members also pointed to the general limits of the law in ensuring inclusive processes. Indeed, deficiencies in accessing the process and its supervision seemed to exist in the implementation of the law between indigenous communities and state representatives at large, as the following extracts illustrate:

'In the prior consultation process they have obviously not succeeded in allowing all affected populations to participate as it is stated in the law, many people do not even know yet, what this means. Besides, participation is reduced by means of the budget which limits the quantity of people who participate.' (In-depth interview in Spanish with indigenous adviser to the process, 10 November 2014)

'The law is not applied here, this is a severe misconduct on the part of the State towards Guaraní people's rights. The State as the competent authority should be monitoring this, this is the State's task.' (In-depth interview in Spanish with indigenous adviser to the process, 10 November 2014)

In all communities that the author visited, similar statements were made as to the relevance of law as an authority mechanism. While specific legal claims remained without substance, the fact that the state was legally obliged to consult the affected communities was clear for everyone. Partly based on their prior knowledge, indigenous advisers to the process and indigenous leaders were the only interviewees who actively used the human rights discourse to strengthen claims or signal violations, as the above shows. Furthermore, the statements reveal how authority was exercised through budgeting 
policies, implementation problems and failed monitoring as one of the key tasks in prior-consultation processes: thereby, the law was used to enforce authority (von Benda-Beckmann et al., 2012) to presumably take sides with hydrocarbon companies in a continuing struggle of land and resources on indigenous territories. In that sense, collective-rights processes that are inherently political in the way control and power determine the distribution and say over natural resources assume depoliticised functions (McNeish, 2013) and monitor communities (Ferguson, 1994) instead of companies and arbitrary practice.

\section{The role of law in a current socio-environmental land conflict}

One of the most current conflicts between the Bolivian government and indigenous communities evolves around the construction of a highway connecting the country's highlands and lowlands through the Amazonian biosphere and national park, Isiboro Sécure National Park and Indigenous Territory (TIPNIS). The conflict has been described as amounting to dangers of extinction for inhabiting indigenous people and even as a form of ethnocide that exemplified the irreversible disappearance, assimilation and expulsion of indigenous communities (Colque, 2017); it concerned thirty-three indigenous Moxeño, Yuracaré and Chimane indigenous communities. While protest that arose in 2011 met with disproportionate violent responses (Bolivian Office of the Ombudsman, 2011) that eventually halted the construction and rendered the park 'intangible' (Postero, 2017) or 'untouchable' (McCormick, 2017), the issue was taken up in summer 2016 and finalised in the legislative act No. 969, 'Law on the Protection, Comprehensive and Sustainable Development of the Indigenous Territory and National Park Isiboro Sécure TIPNIS', giving permission to the infrastructure project.

Additional pressures are exerted on the part of transnational companies in the gas sector that exercise explorative activities in or near the national park TIPNIS (Saavedra, 2017). In fact, the TIPNIS conflict was described as an 'emblematic case of ethno-ecologist resistance against extractive developmentalist policies' (Lalander, 2017, p. 466) with a specific focus on the conflict between indigenous rights and state conduct. Again, indigenous communities represent differing if not contradicting agendas that characterise a complex interplay of interests, including development initiatives such as measures in the education and health sectors on the one hand and protection against environmental destruction and forced relocation on the other. Indigenous entities such as the highlands organisation, the National Council of Ayllus and Markas of Qullasuyu (Consejo Nacional de Ayllus y Markas del Qullasuyu, CONAMAQ), and the lowlands organisation, the Confederation of Indigenous Peoples of Bolivia (Confederación de Pueblos Indígenas de Bolivia, CIDOB), co-organised so-called indigenous marches for territory and dignity as a form of protest. Yet, current positions reveal great fragmentations in the initial collective struggle.

CIDOB's new President Pedro Vare stated unequivocally: 'Our communities need development: we are not animals that only live off nature or like simple birds' (Periódico Digital ERBOL, 2017, first paragraph). Similarly, Guaraní Chief Justa Cabrera indicated two years after the consultations that she would lead the process in a new direction in the name of the entirety of Guaraní organisations (Buttkereit, 2014). Indeed, the TIPNIS case is full of contrasts reflecting the government's efforts to implement its development plans and adverse conduct impacting on indigenous peoples' lives and territories (Postero, 2017). At the same time, the case becomes a symbolic form of internal colonisation involving powerful highland groups that settled in the lowlands to grow coca and deforested lands in the TIPNIS area (Paz, 2012). Evo Morales also gained a significant role in the conflict due to his former position as the leader of a powerful Cocalero organisation that has considerable interests in acquiring new territories: the coca-growing economy was accompanied by economic as well as social, political and cultural assimilation (Colque, 2017) of indigenous identities, with a dispossessing effect. Critics even consider his and his government's treatment of lowland peoples in the TIPNIS conflict a form of internal colonialism, resulting in weakening of the indigenous movement (Canessa, 2014).

It is this scenario in which legal-protection mechanisms become essential for micro-level politics and indigenous lowland communities. Similarly to the previously described case, gender relations 
too are played out differently in relation to encounters with the state. Namely, Evo Morales openly encouraged highland people to seduce indigenous lowland women to get their support (Postero, 2017) in order to gain powerful voices in the consultation, but also regarding the land-titling processes: colonisation clearly adopts a gender dimension as relationships with female indigenous community members come with land rights (Canessa, 2012a), reflecting the practice of conquest since the colonial period (Canessa, 2012b). This, in turn, also meant that collective resistance processes equally stood for gender-related rights and female empowerment in participation mechanisms: in fact, several female chiefs took a lead in the marches of protest, embodying a particularly strong form of female resistance as an elementary pillar of the collective-rights framework.

Beyond gender-related issues, TIPNIS made serious impacts on the community level, where members maintain diverse positions vis-à-vis natural-resource extraction revealing stronger or respective weaker associations with the outside world and, relatedly, trade and market mechanisms (McNeish, 2013). To some extent, this explains communities' different use of the law: while UNDRIPS was adopted to advance indigenous peoples' rights protection, participation mechanisms are used to enhance popular support and legitimacy of a controversial infrastructure project in this case. In that sense, particular groups in the communities and the state use universally recognised legal mechanisms to implement certain agendas. It could be argued that competing demands that existed in terms of territory, nature and ultimately resource sovereignty in the TIPNIS case (Laing, 2015) were harmonised and smoothed out to the detriment of community members opposing the project. Stronger concerns were voiced by the Bolivian Office of the Ombudsman, according to which the consultation with the communities was implemented in a colonialist and unilateral way and violated the constitutional requirement of reaching all parties' consensus (Achtenberg, 2012).

Similarly to the case of the Guaraní people's participation in a prior-consultation case, the TIPNIS conflict reveals how a globally promoted legal regime finds expression in local contexts, yet fails to reach the objective of obtaining FPIC and to be built on genuine dialogue respecting the principle of good faith. Law thereby converts into a disempowering tool that arguably considers majority interests while pretending to promote equality-enhancing and asymmetry-erasing functions. Cultural/ethnic rights enter into direct legal disputes with social and distributional rights: natural-resource extraction offers economic benefits for the population at large, yet violates minorities' cultural and subsistence claims. In that sense, critical voices consider the TIPNIS consultation a mere disputemanagement mechanism that potentially exacerbates conflict rather than solving it while selecting voices to be considered (Fontana and Grugel, 2016). Thereby, 'UNDRIPS on the ground' develops a somewhat contradictory logic according to which indigenous peoples should be protected from suffering historic injustices in terms of their colonisation and dispossession of resources and lands. In addition, indigenous peoples' social structures, traditions and decision-making practice are not respected in accordance with the UNDRIPS framework; rather, such structures are fragmented and played off against each other: during the TIPNIS consultation, individual communities were considered in negotiations rather than local and regional indigenous institutions, and hence violated the institutional set-up of indigenous organisations (Colque, 2017).

Another legal mechanism that catalyses indigenous responses to the law is the protective-areas regime, which has been abolished by several presidential decrees and has resulted in eleven out of twenty-two areas being used for oil and gas concessions according to Bolivia's Documentation and Information Centre (Centro de Documentación e Información Bolivia) - more than one-third in the case of TIPNIS (Lalander, 2017). That way, lowland indigenous peoples' marches and other peaceful means of confronting failed legal regimes could be regarded as desperate attempts to establish internal safeguarding mechanisms to protect not only social, cultural and political rights, but also environmental interests. Such mechanisms further or prolong Evo Morales's promises towards Pachamama or Mother Earth on the ground that are no longer upheld by the government in past and current policies or national discourses (Postero, 2013).

In light of current constitutional violations and failed international human rights commitments, indigenous peoples' mobilisations, protests and road blocks convert into a form of quasi-judicial 
constitutional safeguard while assuming watchdog functions regarding state policies and corporate conduct. In the resolution (001/2017) of the $12^{\text {th }}$ Extraordinary Meeting of Indigenous Nations and Peoples of the TIPNIS (25-28 August 2017) that calls on international institutions to act, indigenous TIPNIS communities explicitly evoke the concepts 'ethnocide' and 'biocide' in the context of the government's approval of the highway project - a last attempt to use international law as an urgent safeguarding mechanism. However, linking indigenous demands with environmental justice concerns, also on the part of environmentalists and NGOs (Fabricant and Postero, forthcoming), comes with the danger of wrongly attributed agency: the Morales government has repeatedly seen NGOs and environmentalist organisations as the main forces behind indigenous mobilisations absolving the latter from genuine decision-making capacities.

\section{Lessons learnt from legal practice in indigenous communities}

Existing legal instruments including ILO C169 and UNDRIPS do little to specify how prior consultation could be designed to achieve more participation and inclusiveness, let alone setting minimum standards for the budget or location of such processes. This is left to the states in the implementation process at the national level, including detailed laws, policies and regulations. Another role could be played by international and regional jurisprudence. Yet, present institutions adopted a rather conservative or cautious stance towards defining obligations that go beyond respecting indigenous peoples' customs and traditions and representative authorities in decision-making processes with the state. The rather broad terms of legal provisions suggest that individual interests and private gain could be isolated from collective-rights debates (Masaki, 2010) at the same time as participating actors are considered black boxes (Luhmann, 1984) that first and foremost represent a common good (Thede, 2011). While international human rights mechanisms point at the problems that stem from selecting leaders for negotiations with state and companies, ${ }^{15}$ specific suggestions on prevention are not made. In a similar vein, the Inter-American Court of Human Rights (IACtHR, 2012) condemns bribing practices or negotiations with individual community members that could potentially subvert the social cohesion in the communities; it further states that representative issues should be decided by the communities instead of the states, but fails to specify detailed obligations in that regard. ${ }^{16}$

However, issues of representation and indigenous internal decision-makers with mandates to negotiate with externals are decisive for the legal-implementation process. This includes mechanisms that translate local dynamics and leadership that have developed at intra-indigenous levels to indigenousstate encounters achieving a form of genuine interlegality (de Sousa Santos, 1995). Indeed, multiple jurisdictional legal hierarchies are critical for cultural identities to become pluralised (Benhabib, 2002); in such encounters, the recognition of legal systems is fundamental. In the prior-consultation process, indigenous elites are explicitly supported by the state that enhances corruptive practices and bribery, especially in light of the high compensation payments that are administered by leaders who hold non-remunerated mandates. In fact, indigenous decision-making institutions were never meant to function as financial administration units; instead, they were originally established to reflect and transmit decisions taken at the community level - Guaraní Mburuvichereta (indigenous leaders) merely served as spokespersons for their communities (Postero, 2007; Hirsch, 1999). In the current setting, where leaders meet with state representatives, controlling functions taken by other community members in local assemblies are largely non-existent. This alludes to the earlier described democratic deficit in the preceding chapters. Namely, women and elderly councils are regarded as important counterweights in assemblies that were originally dominated by male, middle-aged leaders. Similar

\footnotetext{
${ }^{15}$ The UN Permanent Forum on Indigenous Issues made such observations in the Report of the International Expert Group Meeting on Extractive Industries, Indigenous Peoples' Rights and Corporate Social Responsibility (E/C.19/2009/ CRP.8) in 2009.

${ }^{16}$ IACtHR issued a decision in 2012 that made explicit reference to the outlined dilemma in prior consultation, namely in Inter-American Court of Human Rights (2012) Kichwa Indigenous People of Sarayaku v. Ecuador, judgment of June 27, 2012, Serie C, Costa Rica.
} 
practice is shown in the TIPNIS conflict, where female chiefs take a lead in demanding collectiverights guarantees for their communities.

In light of these deficiencies in indigenous encounters with the state through prior-consultation processes, the author proposes a number of positive measures that could be used to clarify and more clearly define the state's legal obligations towards indigenous peoples in the extractive and infrastructure sectors. First, states should be encouraged to guarantee more inclusive assemblies by adjusting budgets to allow more participants, locations to increase accessibility and settings of meetings, such as by ensuring bilingual negotiations. Further, other related availability such as female household obligations and agricultural labour-related availability should be included in the planning process of the consultation. Another problem inherent in the current system is the uneven distribution of 'participation spots' among the communities, which leads to uninformed communities in some cases. This could be mainly attributed to the fact that a small number of selected leaders on the part of the state invites family members and other acquaintances instead of other communities who are left out as a consequence. It is fundamental to include more indigenous representatives from different communities, thereby having a wider geographical reach: the outlined planning process in the regulation should explicitly include references to geographical scope and quantities that are more representative. At the same time, special care should be taken in convening unambiguous consultation processes that do not include official and 'shadow consultations' with selective members, but attempt to achieve universal participation among affected communities and representatives.

Second, existing decision-making mandates should be permanently financially and institutionally supported to prevent bribing and corruptive practices: in the current situation, participation is funded on an ad-hoc basis; not even meetings among participants between official assemblies with the state are facilitated. Similarly, the system of indigenous advisers lacks sustainability and turns this into a highly unattractive, short-term consultancy: indigenous lawyers and engineers from the communities prefer finding jobs on the city. Therefore, the existing law would need to be extended, going beyond 'respecting customs and traditions', as these can only be upheld in large-scale assemblies by means of explicit support. In fact, the current law and regulation entail mainly negative obligations, yet the pure scale of the process in terms of participants, transport, accommodation, food, etc. requires additional measures in addition to expert advice and language requirements that would need accompanying support. Additionally, the TIPNIS case demonstrates the need that comes with integrating isolated communities into the process, requiring additional means of transport to and from remote communities, but also from indigenous headquarters in distanced cities.

Third, the rights granting the role of the state would need to be reaffirmed, separating it from purely corporate interests. To include socio-environmental monitoring units of the Hydrocarbons and Energy Ministry (Ministerio de Hidrocarburos y Energía, MHE) would not be sufficient in that regard: instead, different ministries, including culture, indigenous affairs and the environment, should be attributed key roles in the existing law, which was elaborated on for the hydrocarbon sector in particular. Different parts of the law attribute a role to the MHE in the prior-consultation process, including the final say whenever negotiations fail. Other ministries should be ascribed different tasks throughout the consultation process and especially the final decision, which could enhance bona fide and the principle of consent in the Bolivian context. In the case of the mega infrastructure project TIPNIS, strong regional interests consisting of connecting different Latin American states are at stake; such strong economic lobbies should require additional sensitivity and measures on the part of the state when dealing with human rights and environmental concerns at the community level.

Fourth, further institutional support should be allowed to decrease asymmetries created by the law: apart from funding and allowing indigenous advisers, civil society, legal and engineering advice could play an essential role in ensuring that expert knowledge is transmitted to all affected communities prior to, during and in the aftermath of the consultation process. The communities repeatedly noted the level of 'unpreparedness' and lack of understanding among community members, but also local leaders. At present, only companies are allowed to participate as official parties to the process according to law and regulation. Throughout the TIPNIS negotiations, observers, NGOs and 
international advisers were explicitly prevented from participating in the prior-consultation process; indigenous communities were not allowed to seek such advice despite their decision-making powers and self-determination by law. In other jurisdictions, capacity-building grants and subsidised expert fees for community groups have become part and parcel of the law in addition to prior-consultation procedures. However, in the case at hand, experts' roles in prior-consultation processes remain to be institutionalised and to become transversal issues in negotiations with the state and companies.

Finally, to address one of the core deficiencies as elaborated on above, women's newly acquired positions would also need to be institutionally translated into prior consultations. This could include quota of women in the law or explicit invitations to female representatives, or, alternatively, subelections at a local level in accordance with traditional decision-making structures to ensure female representation throughout the consultation process. In the first planning meeting of the process, female mandate holders should be specifically invited to pronounce themselves on these issues and to reserve 'participation spots' for their peers. Again, the TIPNIS issue illustrated how prominent female figures could not reach official meetings and could solely use political powers throughout the protests and mobilisations without any impact on the official result of decision-making processes.

\section{Conclusions}

The Bolivian case discloses the contradictions and complexities that exist side by side in international indigenous rights commitments, recent dispossessing laws and policies, and generally framed laws and regulations in the hydrocarbon and infrastructure sector that are implemented to the detriment of numerous communities and community members. While prior-consultation processes with Guaraní people are generally implemented according to the law, broad provisions on indigenous peoples' customs and traditions do not find full expression in practice. Rather, indigenous peoples' voices reveal how local empowering dynamics to include women and the elderly are not adequately translated into assemblies that are held by the state. Thereby, the inclusive and participatory character of Guaraní traditional decision-making bodies is disregarded in light of the positive measures lacking on the part of the state and its representative institutions. In the TIPNIS case, legal mechanisms even dispossess indigenous representatives of important decision-making powers and impact on the final result of processes.

In that sense, the law is not only created by the state, revealing demarcation of power (Koskenniemi, 2001 ); it also evolves into a tool of dispossession in community practice. At the same time, the contradictions in collective legal regimes that presuppose the existence of homogenous collective wholes disregard the effects of neoliberalism and their transformative role on indigenous identities and their expression in encounters with the state (Comaroff and Comaroff, 2009). This includes adverse impacts on indigenous leaders and traditional decision-making mechanisms, which are subverted due to external influence such as limited funding that allows elitism to develop. The law presupposes, and it could be argued, that it establishes societal relationships that are based on collective claims that necessarily reflect the common good (Shah, 2007; Kuper, 2003). However, 'collective units' need to be properly understood and disentangled in order to decide who decides. This is not to question indigenous collective claims per se, yet the law could be specified in order to prevent misuse and enable indigenous decision-making to flourish in accordance with customs and traditions. Otherwise, indigenous peoples' right to prior consultation, which was meant to be an expression of collective self-determination, could be reduced as an administrative, depoliticised procedure (Perreault, 2015) or a debate around legal procedures (Rodríguez-Garavito, 2011). The empowering societal impact that inspired its creators vanishes in the latter case. In the cases at hand, legal procedures prioritise the populations' majority interests with little room for manoeuvre for indigenous chiefs.

It is thus proposed to enhance the participatory potential in a number of ways, including clearly outlining positive measures that (1) improve the setting (budget, location, language factors) in priorconsultation meetings with the state, (2) establish permanent institutional and financial support for consultation-related decision-making structures, (3) relocate and restruct prior-consultation units in 
ministries and thereby involve other relevant ministries, (4) establish further support for experts, including from civil society organisations, in terms of legal and engineering expertise (also extending to socio-environmental issues) and (5) provide support to particularly marginalised groups within the communities that play significant roles in local community structures and decision-making. In the observed case, this encompasses indigenous women who have gained strong leadership and, to an albeit less visible extent, indigenous elders councils who are increasingly left out due to a strong middle-aged male leadership.

\section{References}

Achtenberg E (2012) Bolivia: End of the Road for TIPNIS Consulta, North American Congress on Latin America, Rebel Currents, NACLA Report on the Americas.

Ackerman LA and Klein LF (2000) Women and Power in Native North America. Norman: University of Oklahoma Press. Albró R (2010) Confounding cultural citizenship and constitutional reform in Bolivia. Latin American Perspectives 37, $216-$ 233.

Anaya J (2009) The right of indigenous peoples to self-determination in the post declaration era. In Charters C and Stavenhagen R (eds), Making the Declaration Work: The United Nations Declaration on the Rights of Indigenous Peoples. Copenhagen: Eks-Skolens Trykkeri.

Andreucci D and Radhuber IM (2015) Limits to 'counter-neoliberal' reform: mining expansion and the marginalisation of post-extractivist forces in Evo Morales's Bolivia. Geoforum 9, 288.

Baldi CA (2012) New Latin American constitutionalism: challenging Eurocentrism and decolonizing history. Critical Legal Thinking: Law \& the Political. Available at http://criticallegalthinking.com/2012/02/06/new-latin-american-constitutionalism-challenging-eurocentrism-decolonizing-history (accessed 24 May 2018).

Bascopé Sanjinés I (2012) Madre Tierra y Estado Plurinacional: Análisis sobre la construcción, contenidos y viabilidad de la ley de la Madre Tierra. La Paz: El País.

BBC Mundo (2017) El Tribunal Constitutional de Bolivia autoriza a Evo Morales a buscar la reelección como presidente sin límites, BBC Mundo. Available at http://www.bbc.com/mundo/noticias-america-latina-42159445 (accessed 24 May 2018).

Behabib S (2002) The Claims of Culture: Equality and Diversity in the Global Era. Princeton: Princeton University Press.

Böhrt Irahola C (2010) Introducción al nuevo sistema constitucional boliviano, International Institute for Democracy and Electoral Assistance. Stockholm: International IDEA.

Bolivian Office of the Ombudsman (2011) Informe Defensorial Respecto a la Violación de los Derechos Humanos en la Marcha Indígena. La Paz: Defensoría del Pueblo de Bolivia.

Buttkereit H (2014) TIPNIS-Anführerin unterstützt Evo Morales. amerika21: Nachrichten und Analysen aus Lateinamerika. Available at https://amerika21.de/2014/08/103631/morales-unterstuetzerin (accessed 24 May 2018).

Canessa A (2012a) Conflict, claim and contradiction in the new indigenous state of Bolivia. Working Paper Series desiguALdades.net 22, 1-40.

Canessa A (2012b) Intimate Indigeneities: Race, Sex and History in the Small Spaces of Andean Life. Durham: Duke University Press.

Canessa A (2014) Conflict, claim and contradiction in the new 'indigenous' state of Bolivia. Critique of Anthropology 34, 153-173.

Clavero B (2010) Bolivia entre constitucionalismo colonial y constitucionalismo emancipatorio. In Moisés Chivi Vargas I (ed.), Bolivia, Nueva Constitución Política del Estado: Conceptos elementales para su desarrollo normativo. La Paz: Convergencia Comunicación Global.

Colque G (2017) TIPNIS bajo asedio. La Paz: Fundación TIERRA.

Comaroff J and Comaroff JL (2008) Law and Disorder in the Postcolony. Chicago: Chicago University Press.

Comaroff J and Comaroff JL (2009) Ethnicity, Inc. Chicago: University of Chicago Press.

Corntassel J and Holder C (2002) Indigenous peoples and multicultural citizenship: bridging collective and individual rights. Human Rights Quarterly 24, 126-151.

de Sousa Santos B (1995) Toward a New Common Sense: Law, Science and Politics in the Paradigmatic Transition. London: Routledge.

Dresch P and James W (2000) Fieldwork and the passage of time. In Dresch P, James W and Parkin D (eds), Anthropologists in a Wider World. Oxford/New York: Berghahn.

Eichler J (2016) Indigenous peoples' land rights in the Bolivian lowlands: ways to mitigate inequalities in resource-related issues. International Human Rights Law Review 5, 119-145.

Fabricant N and Postero N (2015) Sacrificing indigenous bodies and lands: the political-economic history of lowland Bolivia in light of the recent TIPNIS debate. Journal of Latin American and Caribbean Anthropology 20, 452-474.

Fabricant N and Postero N (2018) Performing indigeneity in Bolivia: the struggle over the TIPNIS. Anthropology Quarterly, forthcoming. 
Ferguson J (1994) The Antipolitics Machine: Development, Depolitization, and Bureaucratic Power in Lesotho. Minneapolis: University of Minnesota Press.

Fontana LB and Grugel J (2016) The politics of indigenous participation through 'free prior and informed consent': reflections from the Bolivian case. World Development 77, 249-261.

Francescone K (2015) Cooperative miners and the politics of abandonment in Bolivia. The Extractive Industries and Society 2, 746-755.

Freeman M (1995) Are there collective human rights? Political Studies 43, 25-40.

Goodale M (2007) The power of right(s): tracking empires of law and new modes of social resistance in Bolivia (and elsewhere). In Goodale M and Merry SE (eds), The Practice of Human Rights: Tracking Law between the Global and the Local. Cambridge: Cambridge University Press.

Guardian, The (2016) Bolivia's president Evo Morales to run again despite referendum ruling it out, The Guardian, 18 December. Available at https://www.theguardian.com/world/2016/dec/18/bolivias-president-evo-morales-to-run-againdespite-referendum-ruling-it-out (accessed 24 May 2018).

Guidi R (2015) Guaraníes de Bolivia protestan nuevas políticas que abren sus territorios a exploración de gas y de petroleo. Mongabay LATAM. Available at https:/es.mongabay.com/2015/10/guaranies-de-bolivia-protestan-nuevas-politicas-queabren-sus-territorios-a-exploracion-de-gas-y-de-petroleo/ (accessed 24 May 2018).

Hinojosa L et al. (2015) Gas and development: rural territorial dynamics in Tarija, Bolivia. World Development 73, $105-117$.

Hirsch SM (1999) The Capitanía of the Izozo: the struggle for political autonomy among the Guaraní Indians of eastern Bolivia. In Miller ES (ed.), Peoples of the Gran Chaco. Westport: Greenwood Publishing Group.

Kaup BZ (2010) Powering Up: Latin America's Energy Challenges: Bolivia's Nationalised Natural Gas: Social and Economic Stability under Morales, LSE IDEAS Reports. London: London School of Economics and Political Science.

Koskenniemi M (2001) The Gentle Civiliser of Nations: The Rise and Fall of International Law, 1870-1960. Cambridge: Cambridge University Press.

Kuokkanen R (2012) Self-determination and indigenous women's rights at the intersection of international human rights. Human Rights Quarterly 34, 225-250.

Kuper A (2003) The return of the native. Current Anthropology 44, 389-402.

Laing A (2015) Resource sovereignties in Bolivia: re-conceptualising the relationship between indigenous identities and the environment during the TIPNIS conflict. Bulletin of Latin American Research 34, 149-166.

Lalander R (2017) Ethnic rights and the dilemma of extractive development in plurinational Bolivia. International Journal of Human Rights 21, 464-481.

Layme B (2015) Normas limitan el trabajo de las ONG en Bolivia, Página Siete. Available at http://www.paginasiete.bo/gente/ 2015/8/17/normas-limitan-trabajo-bolivia-66803.html (accessed 24 May 2018).

Lenzerini F (2014) The Culturalization of Human Rights Law. Oxford: Oxford University Press.

López Camacho E (2015) Frontera petrolera crece y afecta a 37 áreas indígenas, Los Tiempos. Available at http://www.cedib. org/post_type_titulares/frontera-petrolera-crece-y-afecta-a-37-areas-indigenas-los-tiempos-28-7-15/ (accessed 24 May 2018).

Lucero JA (2006) Representing 'real Indians': the challenges of indigenous authenticity and strategic constructivism in Ecuador and Bolivia. Latin American Research Review 42, 31-56.

Luhmann N (1984) Soziale Systeme: Grundriß einer allgemeinen Theorie. Frankfurt am Main: Suhrkamp.

Masaki K (2010) Rectifying the anti-politics of citizen participation: insights from the internal politics of a subaltern community in Nepal. Journal of Development Studies 46, 1196-1215.

McCormick M (2017) 'They lied': Bolivia's untouchable Amazon lands at risk once more, The Guardian, 11 September. Available at https://www.theguardian.com/environment/2017/sep/11/they-lied-bolivia-untouchable-amazon-lands-tipnisat-risk-once-more (accessed 24 May 2018).

McKay MC and Benjamin C (2010) A vision for fulfilling the indivisible rights of indivisible rights of indigenous women. In Hartley J, Joffe P and Preston J (eds), Realizing the UN Declaration on the Rights of Indigenous Peoples: Triumph, Hope, and Action. Vancouver: Purich Publishing Ltd.

McNeish J-A (2013) Extraction, protest and indigeneity in Bolivia: the TIPNIS effect. Latin American and Caribbean Ethnic Studies 8, 221-242.

Merry SE (2006a) Anthropology and international law. Annual Review of Anthropology 35, 99-116.

Merry SE (2006b) Human Rights and Gender Violence: Translating International Law into Local Justice. Chicago: University of Chicago Press.

Merry SE (2006c) Transnational human rights and local activism: mapping the middle. American Anthropologist 108, 38-51.

Muguerza L (2011) El Proceso de Construcción de una Práctica Tuitiva de Derechos y su Afectación por una Coyuntura Adversa: el Caso Boliviano. In Martínez FR (ed.), Los derechos en Latinoamérica: tendencias judiciales recientes. Madrid: Editorial Complutense.

Paz S (2012) La marche indígena del TIPNIS en Bolivia y su relación con los modelos extractivos de América del Sur. Niteroi: Departamento de Geografia, Universidade Federal Fluminense.

Periódico Digital ERBOL (2017) No somos animales para vivir solamente de la naturaleza, ERBOL COMUNICACIONES. Available at http://www.erbol.com.bo/noticia/social/23082017/no_somos_animales_para_vivir_solamente_de_la_naturaleza (accessed 24 May 2018). 
Perreault T (2008) Natural gas, indigenous mobilisation and the Bolivian state. In UNRISD (ed.), Identity, Power and the Rights of Indigenous Peoples. Geneva: United Nations Research Institute for Social Development.

Perreault T (2015) Performing participation: mining, power, and the limits of public consultation in Bolivia. Journal of Latin American and Caribbean Anthropology 20, 433-451.

Pirie F (2013) The Anthropology of Law. Oxford: Oxford University Press.

Postero N (2007) Now We Are Citizens: Indigenous Politics in Postmulticultural Bolivia. Stanford: Stanford University Press.

Postero N (2013) Protecting Mother Earth in Bolivia: discourse and deeds in the Morales administration. In Cooper JM, Hunefeldt C and Acosta Y (eds), Amazonia: Environment and the Law in Amazonia. Eastbourne: Sussex Academic Press.

Postero N (2017) The Indigenous State: Race, Politics, and Performance in Plurinational Bolivia. Oakland: University of California Press.

Pred A and Watts M (1992) Reworking Modernity: Capitalisms and Symbolic Discontent. New Jersey: Rutgers University Press.

Regino Montes A and Torres Cisneros G (2009) The United Nations Declaration on the Rights of Indigenous Peoples: the foundation of a new relationship between indigenous peoples, states and societies. In Charters C and Stavenhagen R (eds), Making the Declaration Work: The United Nations Declaration on the Rights of Indigenous Peoples. Copenhagen: Eks-Skolens Trykkeri.

Robb K et al. (2015) Indigenous Governance and Mining in Bolivia, Report for International Mining for Development Centre (IM4DC). Queensland: Institute for Social Science Research, The University of Queensland.

Robyn E, McNeish J-A and Cimadamore AD (2005) Indigenous Peoples and Poverty: An International Perspective. London: Zed Books.

Rodríguez-Garavito C (2011) Ethnicity.gov global governance, indigenous peoples, and the right to prior consultation in social minefields. Indiana Journal of Global Legal Studies 18, 263-305.

Saavedra JL (2017) Territorios indígenas: agresión petrolera e impunidad oficial. Pukara: cultura, sociedad y política de los pueblos originarios 11, 2-15.

Schilling-Vacaflor A (2014) Contestations Over Indigenous Participation in Bolivia's Extractive Industry: Ideology, Practices, and Legal Norms, GIGA Working Papers 254. Hamburg: GIGA.

Shah A (2007) The dark side of indigeneity? Indigenous people, rights and development in India. History Compass 5, $1806-1832$.

Sieder R and Sierra MT (2010) Indigenous Women's Access to Justice in Latin America, Chr. Michelsen Institute Working Paper 2. Bergen: Chr. Michelsen Institute.

Sneider L (2015) Complementary relationships: a review of indigenous gender studies. In Innes RA and Anderson K (eds), Indigenous Men and Masculinities: Legacies, Identities, Regeneration. Winnipeg: University of Manitoba Press.

Souza LM (1997) Women and crime in colonial Oaxaca: evidence of complementary gender roles in Mixtec and Zapotec societies. In Schroeder S, Wood S and Haskett R (eds), Indian Women in Early Mexico. Norman: University of Oklahoma Press.

Thede N (2011) Democratic agency in the local political sphere: reflection on inclusion in Bolivia. Democratization 18, $211-235$.

Toranzo Roca C (2008) Let the mestizos stand up and be counted. In Crabtree J and Whitehead L (eds), Unresolved Tensions: Bolivia Past and Present. Pittsburgh: University of Pittsburgh Press, pp. 35-50.

von Benda-Beckmann F, von Benda-Beckmann K and Griffiths A (2012) The Power of Law in a Transnational World: Anthropological Enquiries. Oxford: Berghahn Books.

Wiessner S (2011) The cultural rights of indigenous peoples: achievements and continuing challenges. European Journal of International Law 22, 121-140.

Willemsen Diaz A (2009) How indigenous peoples' rights reached the UN. In Charters C and Stavenhagen R (eds), Making the Declaration Work: The United Nations Declaration on the Rights of Indigenous Peoples. Copenhagen: Eks-Skolens Trykkeri.

Wolkmer AC and Wolkmer M de FS (2015) Pluralismo Jurídico y Constitucionalismo Emancipador desde el Sur. In de Sousa Santos B and Cunha T (eds), International Colloquium Epistemologies of the South: South-South, South-North and North-South Global Learnings. Coimbra: Centro de Estudos Sociais.

Yrigoyen Fajardo R (2011) Derecho y Jurisdicción Indígena en la Historia Constitucional: De la Sujeción a la Descolonización. In Garavito CR (ed.), El Derecho en América Latina: Los Retos del Siglo XXI. Buenos Aires: Siglo XX.

Cite this article: Eichler J (2018). Neo-extractivist controversies in Bolivia: indigenous perspectives on global norms. International Journal of Law in Context 1-15. https://doi.org/10.1017/S1744552318000150 